\title{
O que é a Filosofia Política? ${ }^{1}$
}

Leo Strauss

\section{I - O Problema da Filosofia Política}

O sentido da filosofia política e seu caráter significativo são tão evidentes hoje como foram desde a época em que a filosofia política surgiu em Atenas. Toda ação política visa ou a preservação ou a mudança. Quando se deseja preservar, almeja-se prevenir mudanças para pior; quando se deseja mudar, almeja-se trazer algo melhor. Toda ação política é, portanto, guiada por algum pensamento sobre o melhor ou o pior. Mas o pensamento a respeito do melhor ou do pior implica pensar o bem. A percepção do bem que dirige todas as nossas ações tem caráter de opinião: já não é mais questionado, porém, refletindo-se, prova-se questionável. $\mathrm{O}$ fato de que podemos questioná-la, direciona-nos a um pensamento sobre o bem que não é mais questionável rumo a um pensamento que não é mais opinião, mas conhecimento. Toda ação política contém em si mesma um direcionamento ao conhecimento do bem: a boa vida, ou a boa sociedade. Já que a boa sociedade é o bem político completo.

Se esse direcionamento torna-se explícito, a filosofia política emerge quando os homens assumem explicitamente 0 objetivo de adquirir conhecimento sobre a boa vida e a boa sociedade. Ao chamar essa busca de filosofia política, afirmamos que ela forma uma parte de um conjunto maior: a filosofia. Uma vez que a filosofia política é um ramo da filosofia, mesmo a explicação mais provisória do que é a filosofia política não pode dispensar a explicação, ainda que provisória, do que é a filosofia. Filosofia, entendida como a busca pela sabedoria, é uma busca por conhecimento universal, pelo conhecimento como um todo. Essa busca não seria necessária se tal conhecimento estivesse acessível imediatamente. A ausência de

\footnotetext{
${ }^{1}$ Originalmente publicado como What is Political Philosophy? (The Journal of Politics, v. 19, n. 3, p. 343368, 1957). Tradução de Francesca Cricelli. Publicado com permissão gentilmente cedida pela Cambridge University Press para a Leviathan - Cadernos de Pesquisa Política. É possível acessar o original em http://journals. cambridge.org/action/displaylssue?decade $=1950 \&$ jid=JOP\&volumeld $=19$ \&issueld $=03 \&$ iid $=6$ $\underline{375044 .}$
} 
conhecimento do todo não quer dizer, entretanto, que os homens não têm pensamentos sobre o todo: a filosofia é necessariamente precedida por opiniões sobre o que é o todo. A filosofia é, portanto, a tentativa de substituir opiniões sobre o todo pelo conhecimento do todo. Em lugar de "o todo" os filósofos também dizem "todas as coisas"; o todo não é puro éter ou uma escuridão irremediável na qual não é possível distinguir uma parte da outra, ou algo em que não se pode discernir coisa alguma. Uma busca pelo conhecimento de "todas as coisas" significa a busca pelo conhecimento de Deus, do mundo, do homem ou então a busca pelo conhecimento da natureza de todas as coisas: as naturezas em sua totalidade são "o todo".

Essencialmente, a filosofia é não a posse da verdade, mas a busca pela verdade. O traço distintivo do filósofo é que "ele sabe que nada sabe", o seu insight sobre a nossa ignorância sobre as coisas mais importantes o leva a lutar com todas as suas forças pelo conhecimento. Ele deixaria de ser um filósofo se evitasse as questões sobre essas coisas ou se as desconsiderasse porque não podem ser respondidas. Pode ser que em relação às possíveis respostas a essas questões, os prós e os contras estarão mais ou menos em equilíbrio e, portanto, o estágio de discussão ou disputa nunca alcançará o estágio de decisão. Isso não faz a filosofia ser fútil. A apreensão clara de uma questão fundamental exige a compreensão da natureza do assunto com o qual a questão está ligada. Conhecimento genuíno de uma questão fundamental, a compreensão completa da mesma, é melhor do que a cegueira a ela, ou da indiferença a ela, seja essa indiferença ou cegueira acompanhada por conhecimento das respostas a um vasto número de questões periféricas ou efêmeras ou não. Minimum quod potet haberi de cognitione rerum altissimarum, desiderabilius est quam certíssima cognitio quae kabetur de minimis rebus (Tomás Aquino, Summa Theologica, I, qu. 1 a. 5).

Da filosofia assim compreendida, a filosofia política é um ramo. A filosofia política então será uma tentativa de substituir a opinião sobre a natureza das coisas políticas pelo conhecimento da natureza das coisas políticas. Coisas políticas pela sua natureza são submetidas à aprovação ou desaprovação, à escolha ou rejeição, ao elogio ou acusação. Sua essência é não ser neutra, mas sim a de erguer uma reivindicação à obediência, à aliança, à decisão ou ao julgamento dos homens. Não são compreendidas como elas 
são, como coisas políticas, se não se leva a sério sua reivindicação explícita ou implícita de ser julgada em termos de bem ou mal, de justiça ou injustiça, isto é, se não são avaliadas por algum padrão de bem ou justiça. Para julgar de forma fundamentada deve-se conhecer os verdadeiros padrões. Se a filosofia política deseja fazer justiça a seu tema, deve lutar pelo conhecimento verdadeiro desses padrões. A filosofia política é a tentativa de se saber verdadeiramente tanto a natureza das coisas políticas quanto a boa ou correta ordem política.

Todo o conhecimento das coisas políticas implica pressupostos em relação à natureza das coisas políticas, isto é, pressupostos que dizem respeito não apenas à situação política dada, mas à vida política ou humana enquanto tal. Não se pode saber nada sobre uma guerra que acontece em determinada época sem ter alguma noção, ainda que fraca e enevoada, da guerra enquanto tal e seu lugar na vida humana enquanto tal. Não se pode ver um policial sem assumir um pressuposto sobre lei e governo enquanto tais. Os pressupostos sobre a natureza das coisas políticas, que estão implicados em todo o conhecimento das coisas políticas, têm o caráter de opinião. Apenas quando esses pressupostos se tornam tema de uma análise crítica e coerente que uma abordagem filosófica e científica aparece.

O status cognitivo do conhecimento político não é diferente do conhecimento que possui o pastor, o marido, o general, ou o cozinheiro. No entanto, as buscas feitas por esses tipos de homens não fazem surgir a filosofia pastoral, marital, militar ou culinária, porque seus objetivos são suficientemente claros e sem ambiguidades. O fim último da política, por outro lado, convoca urgentemente a uma reflexão coerente. O objetivo do general é a vitória, ao passo que o objetivo do líder político é o bem comum. O que a vitória significa não é essencialmente controverso, mas o sentido do bem comum é essencialmente controverso. A ambiguidade do objetivo político é devido ao seu caráter abrangente. Assim surge a tentação de negar, ou evitar, o caráter abrangente da política e de tratar a política como um compartimento como qualquer outro. Devemos resistir à essa tentação, se quisermos enfrentar nossa situação como seres humanos, isto é, a situação como um todo. 
A filosofia política, tal como tentamos circunscrevê-la, foi cultivada desde o seu início, praticamente sem nenhuma interrupção, até muito recentemente. Hoje, a filosofia política está em um estado de decadência e talvez de putrefação, se é que ainda não desapareceu completamente. Não só há desacordo completo sobre o seu tema, seus métodos e sua função: sua própria existência, em quaisquer de suas formas, tornou-se questionável. $\mathrm{O}$ único ponto sobre o qual os professores de ciência política ainda concordam se refere à utilidade de se estudar a história da filosofia política. Em relação aos filósofos, é suficiente comparar a obra de quatro dos maiores filósofos dos últimos 40 anos - Bergson, Whitehead, Husserl e Heidegger - com a obra de Hermann Cohen para notarmos o quanto e quão rapidamente a filosofia política tornou-se desacreditada. Podemos descrever a atual situação da seguinte forma: na sua origem, a filosofia política era idêntica à ciência política, e era um estudo abrangente dos assuntos humanos. Hoje, notamos que ela foi cortada em pedaços que se comportam como partes de uma minhoca. Em primeiro lugar, aplicou-se uma separação entre filosofia e ciência, fez-se uma separação entre a ciência política não filosófica e uma filosofia política não científica, uma separação, que nas atuais condições, retira toda a dignidade e toda a honestidade da filosofia política. Mais ainda, extensos segmentos que antes pertenciam à filosofia política ou à ciência política se emanciparam sob os nomes de economia, sociologia e psicologia social. $\mathrm{O}$ triste resto desconsiderado pelos cientistas sociais honestos é deixado como presa aos filósofos da história e a pessoas que se impressionam mais facilmente que outras com profissões de fé. Nunca se exagera quando se diz que hoje a filosofia política não existe mais, exceto como material para um enterro, isto é, para pesquisa histórica, ou como um tema de protestos débeis e não convincentes.

Se perguntarmos sobre as razões para essa grande mudança, receberemos essas respostas: a filosofia política não é científica, ou não é histórica, ou ambos. Ciência e história, esses dois grandes poderes do mundo moderno, em algum momento, conseguiram destruir até mesmo a possibilidade da filosofia política.

A rejeição da filosofia política como não científica é uma característica do positivismo atual. O positivismo não é mais o que desejava ser quando 
Auguste Comte o iniciou. O positivismo ainda concorda com Comte ao sustentar que a ciência moderna é a forma mais elevada de conhecimento, precisamente porque não busca mais, como buscaram a teologia e a metafísica, o conhecimento absoluto do "Por Que", mas o conhecimento relativo do "Como". Mas, depois de ter sido modificado pelo utilitarismo, evolucionismo e neokantismo, o positivismo abandonou completamente a esperança de Comte de que a ciência social modelada na ciência natural moderna seria capaz de superar a anarquia intelectual da sociedade moderna. $\mathrm{Na}$ última década do século XIX, o positivismo da ciência social alcançou sua forma final ao constatar ou decretar que há uma diferença fundamental entre fatos e valores, e que apenas julgamentos factuais estão dentro da competência da ciência: a ciência social científica é incompetente para pronunciar julgamentos de valor e deve mesmo evitá-los. Em relação ao sentido do termo "valor" em afirmações desse tipo, não podemos dizer nada mais além de que o termo "valores" significa tanto as coisas preferidas como os princípios da preferência.

Uma discussão sobre os princípios da ciência social positivista é indispensável para explicar o sentido da filosofia política. Devemos reconsiderar especialmente as consequências práticas desse positivismo. A ciência social positivista é "livre de valores" ou "eticamente neutra": é neutra no conflito entre o bem e o mal, seja lá o que se entenda por bem e mal. Isso quer dizer que o terreno que é comum a todos os cientistas sociais, o terreno no qual eles levam suas pesquisas e discussões adiante, só pode ser alcançado por um processo de emancipação dos julgamentos morais: ignorância moral é a condição necessária para a análise científica. Devido ao fato de que não somos completamente insensíveis a distinções morais, somos forçados a fazer julgamentos de valor. O hábito de olhar para fenômenos sociais ou humanos sem fazer julgamentos morais tem uma influência corrosiva sobre quaisquer preferências. Somos tão mais sérios como cientistas sociais à medida que desenvolvemos tão mais completamente dentro de nós mesmos um estado de indiferença em relação a qualquer meta ou ainda um estado de falta de propósito e perda de rumo, um estado que pode ser chamado de nilismo. O cientista social não está imune a preferências; sua atividade é uma luta constante contra as preferências que ele tem como ser humano e cidadão e 
que ameaçam dominar seu distanciamento científico. Ele extrai o poder de se contrapor a essas influências perigosas de sua dedicação a um e apenas um valor: a verdade. Mas, segundo seus princípios, a verdade não é um valor que necessita ser escolhido: pode-se rejeitá-lo ou escolhê-lo. O cientista enquanto cientista deve de fato escolher a verdade. Mas nem cientistas ou a ciência são simplesmente necessários. A ciência social não pode se manifestar sobre a questão da ciência social ser boa em si mesma. Então, é compelida a ensinar que a sociedade pode com igual direito e com igual razão privilegiar a ciência social assim como suprimi-la como perturbadora, subversiva, corrosiva, niilista. Mas, estranhamente, encontramos cientistas sociais muito ansiosos para "vender" a ciência social, ou seja, provar que a ciência social é necessária. Eles argumentarão da seguinte maneira. Independentemente de quais forem as nossas preferências ou fins, nós desejamos alcançá-los; para fazê-lo, devemos saber quais meios levam aos nossos objetivos; mas um conhecimento adequado dos meios que levam a quaisquer fins sociais é a única função da ciência social e somente dela; assim sendo, a ciência social é necessária para qualquer sociedade ou qualquer movimento social; a ciência social é, portanto, simplesmente necessária. É um valor sob qualquer ponto de vista. Mas uma vez que nós chegamos a isso, somos tentados a considerar se não existiriam algumas outras coisas que devem ser valores sob qualquer ponto de vista ou para qualquer ser humano pensante. Para evitar essa inconveniência, o cientista social irá repudiar todas as considerações de relações públicas ou progresso privado e irá se refugiar na afirmação virtuosa de que ele não sabe, mas apenas acredita que a busca pela verdade é boa: outros homens talvez acreditem com igual direito que a busca pela verdade é má. Mas o que ele quer dizer com essa afirmação? Ou ele faz uma distinção entre objetivos nobres e espúrios ou ele se recusa a fazer tal distinção. Se fizer uma distinção entre objetivos nobres e espúrios, dirá que há uma variedade de objetivos nobres ou de ideais, e que não há um ideal que seja comparável com todos os demais ideais: se escolhe a verdade como ideal, rejeita-se necessariamente outros ideais; sendo esse o caso, não pode haver uma necessidade para homens nobres escolherem a verdade como uma preferência em relação a outros ideais. Mas enquanto o cientista social estiver falando de ideais faz uma distinção entre objetivos nobres e não nobres ou 
entre integridade idealista e egoísmo mesquinho; ele faz um juízo de valor que, segundo sua própria afirmação fundamental, não é mais necessário. Ele deve então dizer que é tão legítimo escolher a busca por segurança, renda ou reconhecimento do único objetivo da vida quanto escolher a busca pela verdade. Ele assim faz-se alvo da suspeita de que sua atividade como cientista social serve a nenhum outro propósito que o de aumentar a sua segurança, sua renda, seu prestígio, ou de que sua competência como cientista social é uma habilidade que ele está disposto a vender pelo melhor preço. Cidadãos honestos começarão a pensar se tal homem é confiável, ou se ele pode ser leal, especialmente se argumentar que é tão defensável escolher a lealdade como um valor quanto rejeitá-la. Em poucas palavras, ele ficará emaranhado no conflito que levou à queda de Thrasymachus e sua educação por Sócrates no primeiro livro de $A$ República de Platão.

Não é preciso dizer que, ainda que o nosso cientista social possa ter ficado confuso, ele está longe de ser desleal e de lhe faltar integridade. Sua afirmação de que integridade e busca pela verdade são valores que alguém pode, com igual direito, escolher ou rejeitar é um mero movimento de seus lábios e sua língua, sem correspondência com nada em seu coração ou mente. Eu nunca conheci um cientista social que, aparte ser dedicado à verdade e integridade, não era também completamente devotado à democracia. Quando diz que a democracia é um valor que não é evidentemente superior ao valor oposto, não quer dizer que está atraído pela alternativa que rejeita, ou que seu coração ou sua mente estão divididos entre alternativas que são em si mesmas igualmente atraentes. Sua "neutralidade ética" é tão distante de ser niilista que não é mais do que um álibi para falta de consideração e vulgaridade: ao dizer que democracia e verdade são valores, está na prática dizendo que não se deve pensar sobre as razões porque essas coisas são boas, e que ele pode se curvar, como qualquer outro, aos valores que são adotados e respeitados em sua sociedade. O positivismo da ciência social fomenta não mais o niilismo do que o conformismo e filisteísmo.

Não é necessário entrar aqui e agora em uma discussão sobre a fragilidade teórica do positivismo da ciência social. Basta aludir às considerações que falam de maneira decisiva contra essa escola. 
1. É impossível estudar um fenômeno social, isto é, todos os importantes fenômenos sociais, sem fazer juízos de valor. Um homem que não vê razão para desprezar pessoas cujo horizonte é limitado a seu consumo de comida e sua digestão pode ser um econometrista tolerável; ele não pode dizer nada de relevante sobre o caráter da sociedade humana. Um homem que se recusa a distinguir entre um grande líder político e impostores insanos e medíocres pode ser um bom bibliógrafo; mas não pode dizer nada de relevante sobre política e história política. Um homem que não pode distinguir entre um pensamento profundamente religioso e uma superstição frágil pode ser um bom estatístico; ele não pode dizer nada de relevante sobre sociologia da religião. De maneira geral, é impossível compreender pensamento ou ação ou trabalho sem avaliálos. Se não somos capazes de avaliar adequadamente, como frequentemente é o caso, nós não somos ainda capazes de compreender adequadamente. Os julgamentos de valor que são proibidos de entrar pela porta da frente da ciência política, sociologia ou economia, entram nestas disciplinas pela porta dos fundos; eles vêm daquele anexo da ciência social da atualidade que é chamado de psicopatologia. Cientistas sociais se veem compelidos a falar de pessoas desequilibradas, neuróticas, desajustadas. Mas esses juízos de valor são diferenciados daqueles usados pelos grandes historiadores, não devido a uma maior clareza ou certeza, mas apenas devido à sua pobreza: um operador esperto é tão ajustado quanto ou mais ajustado que um bom homem ou um bom cidadão. Finalmente, nós não devemos deixar de notar os juízos de valor invisíveis, ocultados dos olhos incapazes de discernir, mas mesmo assim muito eficazes em conceitos alegada e puramente descritivos. Por exemplo, quando cientistas sociais fazem uma distinção entre hábitos democráticos e autoritários ou tipos de seres humanos, o que eles chamam de "autoritário" é ao que me parece uma caricatura daquilo que eles, como bons democratas de um certo tipo, desaprovam. Ou quando eles falam de três princípios de legitimação racional, tradicional e carismática - a sua própria expressão "rotinização do carisma" revela uma preferência protestante ou liberal que nenhum judeu ou católico conservador aceitaria: sob a luz da noção de "rotinização do carisma", a gênese do Halakah a partir da profecia bíblica e a gênese da igreja católica a partir dos ensinamentos do Novo Testamento, necessariamente, aparecem como casos de "rotinização do carisma". Se for feita a objeção de que 
julgamentos de valor são inevitáveis na ciência social, mas que têm um caráter meramente condicional, eu diria o seguinte: Não estariam as condições em questão necessariamente atendidas quando estamos interessados em fenômenos sociais? O cientista social poderia deixar de pressupor que uma vida social saudável é boa, da mesma forma que a medicina necessariamente pressupõe que saúde e uma vida saudável e longa são boas? E todas as afirmações baseadas em condições ou pressupostos não se tornam questionáveis desde que lidemos com fatos enquanto fatos (por exemplo, de que há "fatos" e que eventos têm causas)?

A impossibilidade de uma ciência política "livre de valores" pode ser demonstrada da forma mais simples pelo que segue. A ciência política pressupõe a distinção entre coisas políticas e coisas que não são políticas; pressupõe, portanto, alguma resposta para a pergunta "o que é político?". Para que seja verdadeiramente científica, a ciência política deveria fazer essa pergunta e respondê-la de maneira explícita e adequada. Mas é impossível definir o que é político, ou seja, aquilo que é relacionado de maneira relevante à polis, ao país ou ao "Estado" sem responder à pergunta sobre o que constitui esse tipo de sociedade. Porém, a sociedade não pode ser definida sem referência a seu propósito. A tentativa mais conhecida de definir "o Estado" sem recorrer a seu propósito, levou assumidamente a uma definição que foi derivada do "tipo moderno de Estado" e que é totalmente aplicável apenas a esse tipo; foi uma tentativa de definir o Estado moderno sem antes definir o que é Estado. Mas ao se definir o que é Estado, ou então sociedade civil, com referência a sua finalidade, deve-se admitir um padrão sob o qual se deve julgar ações políticas e instituições: o propósito da sociedade civil necessariamente funciona como um padrão para julgar sociedades civis.

2. A rejeição a julgamentos de valor é baseada no pressuposto de que conflitos entre diferentes valores ou sistemas de valores são essencialmente insolúveis para a razão humana. Mas esse pressuposto, embora considerado bem estabelecido, nunca foi provado. Sua prova exigiria esforço de magnitude equivalente a que foi investida na concepção e elaboração da Crítica da Razão Pura; exigiria uma crítica abrangente da avaliação da razão. O que encontramos na realidade são observações esquemáticas que pretendem provar que este ou aquele conflito de valor é insolúvel. É prudente reconhecer 
que há de fato conflitos de valores que não podem ser resolvidos pela razão humana. Mas se não podemos resolver qual entre duas montanhas cujos cumes estão cobertos de nuvens é maior do que a outra, não poderíamos ainda assim decidir que a montanha é mais alta do que um montículo de terra feito por um tatu? Se não podemos decidir, em uma guerra entre dois países que estiveram guerreando por séculos, qual possui a causa mais justa, não poderíamos decidir que a ação de Jezabel contra Nabote foi indesculpável? 0 maior representante da ciência social positivista, Max Weber, postulou a impossibilidade de solução de todos os conflitos de valores, porque sua alma almejava ao universo, no qual o fracasso, esse bastardo de pecado vigoroso acompanhado pela fé ainda mais vigorosa, em vez de traduzir-se em felicidade e serenidade, tornou-se a marca da nobreza humana. A crença de que julgamentos de valores não são submetidos, afinal, a controle racional, encoraja a inclinação de se fazer afirmações irresponsáveis sobre o certo e o errado ou o bem e o mal. Evita-se discussões de sérias questões pelo simples recurso de apresentá-las como problemas de valores.

3. A crença de que o conhecimento científico - isto é, o tipo de conhecimento que a ciência moderna possui ou aspira - é a forma mais alta do conhecimento humano implica a depreciação do conhecimento pré-científico. Se considerarmos 0 contraste entre 0 conhecimento científico e 0 conhecimento pré-científico do mundo, percebemos a constatação de que o positivismo preserva d e forma pouco disfarçada a dúvida universal de Descartes quanto ao conhecimento pré-científico e sua ruptura radical com ele. Essa dúvida certamente desconfia do conhecimento pré-científico, comparando-o ao folclore. Essa superstição promove toda a sorte de investigações estéreis ou idiotices complicadas. Coisas que toda criança de dez anos de idade de inteligência normal sabe são vistas como demandando provas científicas para tornarem-se aceitáveis como fatos. E essa prova científica não é apenas desnecessária, ela não é possível. Para ilustrar isto pelo exemplo mais simples: todos os estudos nas ciências sociais pressupõem que seus devotos podem diferenciar seres humanos de outros seres; esse conhecimento tão fundamental não foi adquirido por eles em sala de aula; e esse conhecimento não é transformado pela ciência social em conhecimento científico, mas retém seu status inicial sem qualquer modificação até hoje. Se 
esse conhecimento pré-científico não é conhecimento, todos os estudos científicos que permanecem ou sucumbem com ele, não possuem o caráter de conhecimento. A preocupação com a prova científica das coisas que todos sabem suficientemente bem ou melhor sem prova científica, leva a negligenciar aquele pensamento ou aquela reflexão que deve preceder todos os estudos científicos, caso sejam relevantes. O estudo científico da política é frequentemente apresentado como tendo origem na verificação de "fatos" políticos, isto é, do que aconteceu até o momento na política até a formulação de "leis" cujo conhecimento permitiria a previsão de eventos políticos futuros. Esse objetivo é como um roteiro sem uma investigação prévia sobre se a questão com o qual a política lida admite uma compreensão adequada em termos de "leis" ou se as referências por meio das quais as coisas políticas podem ser compreendidas como são não devem ser concebidas em termos completamente diferentes. A preocupação científica com fatos políticos, relações entre fatos políticos, relações recorrentes de fatos políticos ou leis de comportamento político, requer isolamento do fenômeno que está sendo estudado. Porém, se esse isolamento leva a resultados irrelevantes ou equivocados, deve-se ver o fenômeno em questão no todo ao qual ele pertence, e deve-se esclarecer aquele todo, ou seja, a ordem política ou político-social como um todo: por exemplo, não se pode chegar a um tipo de conhecimento de "política de grupos" que mereça ser chamado de científico se não se refletir sobre qual gênero de ordem política é tomado como pressuposto para que exista uma "política de grupos" e que tipo de ordem política é pressuposta pela "política de grupos" específica que está sendo estudada. Não se pode esclarecer o caráter de uma democracia específica ou da democracia em geral sem ter uma compreensão clara das alternativas à democracia. Cientistas políticos tendem a deixar a questão em termos de uma distinção entre democracia e autoritarismo, isto é, eles tornam absoluta a ordem política dada, permanecendo dentro de um horizonte que é definido pela ordem política dada e seu oposto. A abordagem científica tende a negligenciar questões fundamentais e primárias e, com isso, conduzem a uma aceitação irrefletida da opinião recebida. Em relação a essas questões fundamentais, nossos amigos da exatidão científica são estranhamente inexatos. Para me referir novamente ao exemplo mais simples e ao mesmo tempo decisivo, a ciência política exige 
esclarecimento sobre o que distingue coisas políticas de coisas que não são políticas; exige que a pergunta "o que é político?" seja feita e respondida. Essa questão não pode ser abordada cientificamente, mas apenas dialeticamente. E o tratamento dialético começa necessariamente do conhecimento pré-científico e o toma seriamente. O conhecimento pré-científico ou conhecimento de "senso comum" foi considerado desacreditado por Copérnico e pela ciência natural que o sucedeu. Mas o fato de que, o que chamamos de conhecimento telescópico-microscópico seja útil em certas áreas, não permite que se negue que existem coisas que podem ser vistas assim como são, se fossem vistas a olho nu; ou, mais precisamente, se essas coisas fossem vistas na perspectiva do cidadão, em contraste com a perspectiva do observador científico. Se negássemos isso repetiríamos a experiência de Gulliver com a enfermeira em Brobdingnag, pois ficaríamos emaranhados no mesmo tipo de projeto de pesquisa, que lhe causou tanta admiração em Laputa.

4. O positivismo transforma-se, necessariamente, em historicismo. Devido à sua orientação pelo modelo da ciência natural, a ciência social corre o risco de confundir particularidades, por exemplo, confundir os Estados Unidos da metade do século XX, ou de forma mais geral, da sociedade ocidental moderna, com o caráter essencial da sociedade humana. Para evitar esse perigo a ciência social, é levada a se envolver em "pesquisas interculturais", no estudo de outras culturas, tanto atuais como passadas. Mas ao fazer esse esforço, a ciência social perde o sentido dessas culturas, pois as interpreta por meio de um esquema conceitual que se originou na sociedade ocidental moderna, que reflete uma sociedade em particular e que cabe, na melhor das hipóteses, apenas àquela sociedade em particular. Para evitar esse risco, a ciência social deve buscar compreender essas culturas como são compreendidas por elas próprias: a compreensão primariamente exigida do cientista social é a compreensão histórica. A compreensão histórica se torna a base de uma verdadeira ciência empírica da sociedade. Mas se se considera a tarefa infinita da compreensão histórica, começa-se a especular se a compreensão histórica não estaria substituindo o estudo científico da sociedade. Além disso, a ciência social é tida como um conjunto de proposições verdadeiras sobre fenômenos sociais. As proposições são respostas a perguntas. $O$ que são respostas válidas - respostas 
objetivamente válidas - pode ser determinado pelas regras ou princípios da lógica. Mas as perguntas dependem da direção do interesse de uma pessoa e, portanto, dos valores desta, ou seja, de princípios subjetivos. É a direção dos interesses e não a lógica que fornece os conceitos fundamentais. Na ciência social, portanto, não é possível divorciar o elemento subjetivo do objetivo; as perguntas objetivas recebem seu sentido das perguntas subjetivas. Se não se recai em um platonismo decadente que está subjacente à noção de valores permanentes, deve-se conceber os valores incorporados - em dada ciência social - como dependentes da sociedade à qual ela pertence, isto é, na história. A ciência social não é apenas sobreposta pelos estudos históricos, a própria ciência social se mostra "histórica". A reflexão sobre a ciência social como um fenômeno histórico leva à relativização da ciência social e, em última instância, da ciência moderna em geral. Em consequência, a ciência moderna é vista como uma maneira historicamente relativa de compreender as coisas, o que, em princípio, não é uma forma superior àquelas nativas de compreensão.

É somente nesse momento que chegamos a ficar face a face com o verdadeiro antagonismo da filosofia política: o historicismo. Após ter alcançado seu desenvolvimento pleno, o historicismo distingue-se do positivismo pelas seguintes características: (1) abandona a distinção entre fatos e valores, porque toda compreensão, ainda que teórica, implica avaliações específicas; (2) nega o caráter autoritário da ciência moderna, que surge como apenas uma de várias formas de orientação intelectual do homem no mundo; (3) recusa-se a considerar o processo histórico como sendo fundamentalmente progressista, ou, de forma mais geral, como razoável; (4) nega a relevância da tese evolucionista afirmando que a evolução do homem a partir do não-homem não pode tornar sua humanidade inteligível. O historicismo rejeita a ideia da boa sociedade dado o caráter essencialmente histórico da boa sociedade e do pensamento humano: não existe uma necessidade essencial para se apresentar a questão da boa sociedade; essa questão não é, em princípio, contemporânea do homem; sua possibilidade é o resultado de uma misteriosa concessão do destino. A questão crucial diz respeito ao status daquelas características permanentes da humanidade, tais como a distinção entre nobreza e base, que é aceita pelos historicistas mais criteriosos: podem essas permanências serem usadas como critério de distinção entre boas e más 
concessões do destino? As respostas do historicista para essa questão são negativas. Ele despreza as permanências em questão devido a seu caráter objetivo, comum, superficial e rudimentar: para serem relevantes, deveriam ter sido completadas, e sua completude não é mais comum, mas histórica. Foi o desprezo por essas permanências que permitiu aos mais radicais historicistas em 1933 se submeterem, ou darem as boas-vindas, como uma concessão ao destino, ao veredito da parte menos sábia e menos moderada de sua nação enquanto ela estava em seu humor menos sábio e menos moderado, e, ao mesmo tempo, falar de sabedoria e moderação. Os eventos de 1933 provaram, se essa prova era necessária, que o homem não pode abandonar a questão da boa sociedade e que ele não por libertar-se da responsabilidade de responder a ela recorrendo à história ou a qualquer outro poder diferente à sua própria razão.

\section{II - A solução clássica}

Quando descrevemos a filosofia política de Platão e Aristóteles como a filosofia política clássica, nós sugerimos que esta é a forma clássica da filosofia política. Foi dito que o clássico se caracteriza pela nobre simplicidade e grandiosidade silenciosa. Essa sugestão nos leva para a direção correta. É uma tentativa de articular o que era formalmente também chamado de caráter "natural" do pensamento clássico. "Natural" é aqui entendido em contraposição àquilo que é meramente humano, tão humano. Um homem é considerado natural quando guiado pela natureza em vez de pelas convenções, opiniões adquiridas, ou tradição, para não falarmos dos modismos. A filosofia política clássica é não-tradicional, porque pertence ao momento fértil em que todas as tradições políticas foram abaladas e ainda não existia uma tradição de filosofia política. Nas épocas que se seguiram, o estudo das coisas políticas, feito pelos filósofos, foi mediado pela tradição da filosofia política que figurava como uma tela entre o filósofo e as coisas políticas, independentemente se o filósofo abraçasse ou rejeitasse essa tradição. Disso segue que os filósofos clássicos viam as coisas políticas com um frescor e objetividade que nunca mais foram equiparados. Eles olham para as coisas políticas a partir da perspectiva do cidadão esclarecido ou do homem de Estado. Eles veem as coisas claramente 
enquanto o cidadão esclarecido ou o homem de Estado não veem claramente, ou sequer veem. Não há outra razão para isso a não ser o fato de que eles olham na mesma direção e mais longe no horizonte do que os cidadãos esclarecidos e os homens de Estado. Eles não olham para as coisas políticas com olhar externo, como expectadores da vida política. Eles falam a linguagem dos cidadãos ou homens de Estado; eles raramente usam um termo sequer que não seja familiar àqueles que frequentam um mercado. Desse modo, sua filosofia política é abrangente; é tanto teoria como habilidade política; é pertinente aos aspectos legais e institucionais da vida política como àqueles que transcendem o aspecto legal e institucional; é igualmente livre da perspectiva estreita do advogado, da brutalidade do técnico, dos caprichos do visionário e da superficialidade do oportunista. Ela reproduz e eleva à sua perfeição a magnânima flexibilidade do verdadeiro homem do Estado, que esmaga o insolente e poupa o conquistado. É livre de todo fanatismo porque sabe que o mal não pode ser erradicado e, portanto, que as expectativas da política devem ser moderadas. O espírito que a anima pode ser descrito como serenidade ou sublime sobriedade.

Comparada com a filosofia política clássica, todo o pensamento político posterior, independentemente dos méritos que tiver, e em particular 0 pensamento político moderno, tem um caráter pouco original. Isso quer dizer que aconteceu um afastamento de questões simples e primárias. Isso conferiu à filosofia política um caráter de "abstração" e, portanto, engendrou a visão de que o movimento filosófico deve ser um movimento, não da opinião para 0 conhecimento, não do aqui e agora para o que é sempre e eterno, mas do abstrato para o concreto. Pensou-se que pelo simples ato deste movimento em direção ao concreto, a filosofia contemporânea tivesse superado as limitações não só da filosofia política moderna, mas também da filosofia política clássica. Não se percebeu, entretanto, que essa mudança de orientação perpetuou o defeito original da filosofia moderna porque aceitou a abstração como seu ponto de partida, e que o concreto ao qual eventualmente chegou não era o verdadeiramente concreto, mas ainda uma abstração.

Apenas um exemplo é suficiente aqui. Atualmente se alega em certos círculos que a tarefa da ciência política ou social é compreender a mais concreta das relações humanas que é conhecida como a relação "Eu-Você- 
Nós" (I-Thou-We). É fácil perceber que o "Você" e o "Nós" são suplementos do "Ego" de Descartes; a questão é se a inadequação do Ego de Descartes pode ser resolvida por meio de quaisquer suplementos, e se não seria necessário retornar a um início mais fundamental, ou para o início natural. O fenômeno que hoje é chamando de relação "Eu-Você-Nós" era conhecido pelos clássicos pelo nome de amizade. Quando falo com um amigo, eu o chamo na segunda pessoa. Mas a análise filosófica ou científica não está falando a um amigo, ou seja, a esse indivíduo no aqui e agora, mas falando a qualquer um que esteja envolvido em tal análise. Essa não pode ser considerada uma substituição à convivência como amigos; pode no máximo apontar para essa vivência e fomentar o desejo por ela. Quando falo com alguém com quem tenho uma relação próxima eu o chamo meu "amigo". Eu não o chamo "Você" (Thou). De maneira análoga, "falar sobre" no contexto do discurso analítico ou objetivo deve ser fundamentado e continuar da mesma maneira de "falar sobre" que é inerente na vida humana. Ao falar do "você" em vez de "o amigo", estou tentando preservar no discurso objetivo aquilo que não pode ser preservado no discurso objetivo; estou tentando objetivar uma coisa que é impossível de ser objetivada. Estou tentando preservar no "falar sobre" o que pode ser real apenas no "falar a", isto é, comento uma injustiça com o fenômeno; eu sou falso em relação ao fenômeno, eu perco o concreto. Ao tentar estabelecer uma fundação para a comunicação genuinamente humana, preservo a incapacidade para isso.

O caráter da filosofia política clássica aparece com a maior clareza nas Leis de Platão, que é a sua obra política par excellence. As Leis é uma conversa, sobre a lei e coisas políticas em geral, entre um estranho velho ateniense, um velho cretense e um velho espartano. A conversa tem lugar na ilha de Creta. No início, tem-se a impressão que o ateniense veio a Creta para estudar lá as melhores leis. Pois se é verdade que o bom é idêntico ao ancestral, as melhores leis para um grego seriam as leis gregas mais antigas, que eram as leis de Creta. Mas a suposta igualdade entre o bom e o ancestral não é sustentável, se os primeiros ancestrais não eram deuses, ou filhos de deuses, ou pupilos de deuses. Assim, os cretenses acreditavam que suas leis foram criadas por Zeus, que instruiu seu filho Minos, o legislador de Creta. As Leis abrem com uma expressão dessa crença. Segue imediatamente que essa 
crença, não possui outro fundamento, ou não possui melhor fundamento, do que um ditado de Homero - e os poetas são de veracidade questionável, assim diziam os cretenses, e eles eram conhecidos pela falta de veracidade. Ainda que seja assim, logo após seu início, a conversa muda das origens das leis cretenses e espartanas para a questão de seus valores intrínsecos. Um código dado por um deus, Moy, um ser de excelência sobre-humana, deve ser inquestionavelmente bom. Bem devagar, bem discretamente, o ateniense se aproxima dessa grave questão. Para começar, ele limita sua crítica ao princípio que fundamenta os códigos de Creta e Esparta criticando não os códigos, mas um poeta, um homem sem autoridade e, além disso, um expatriado, que elogiou o mesmo princípio. Na sequência, o filósofo ataca, não ainda os códigos de Creta e Esparta, mas a interpretação desses códigos que foi apresentada por seus dois interlocutores. Ele não começa a criticar esses veneráveis códigos legais explicitamente antes de ter apelado a uma suposta lei cretense ou espartana que permite tais críticas sob certas circunstâncias, sob condições que são atendidas, em certa medida, na conversa que está acontecendo. Segundo a lei, todos devem dizer com uma só voz e com uma só boca que todas as leis de Creta ou de Esparta são boas, porque elas foram dadas por deuses, e a ninguém é dado dizer algo diverso disso; mas um velho cidadão pode fazer uma crítica de uma lei supostamente divina diante de um magistrado de mesma idade, se jovens não estiverem presentes. A partir daí, fica claro para o leitor que o ateniense não veio a Creta para estudar as melhores leis, mas para introduzir em Creta novas leis e instituições, leis e instituições verdadeiramente boas. Essas leis e instituições mostrar-se-ão, em grande medida, ser de origem ateniense. Parece que 0 ateniense, sendo 0 filho de uma sociedade altamente civilizada, embarcou em uma missão de civilizar uma sociedade um tanto atrasada. Portanto, ele tem que entender que suas sugestões serão odiosas, não só como inovações, mas acima de tudo como estrangeiras, como atenienses; velhas e profundas animosidades e suspeitas serão fomentadas com suas recomendações. Ele inicia sua crítica explícita com um comentário sobre a provável conexão entre certas instituições cretenses e espartanas e a prática de homossexualidade nessas cidades. O espartano, saindo em defesa de sua pátria, não pretende defender a homossexualidade, mas, tomando a ofensiva, condena os atenienses por 
beberem em excesso. $O$ ateniense então tem a desculpa perfeita para recomendar a introdução da instituição ateniense dos banquetes: é compelido a defender essa instituição e, ao defendê-la, representa não um filósofo civilizador, o qual, sendo um filósofo, é um filantropo, mas, sim, representa um patriota. Ele age de uma forma que é perfeitamente compreensível a seus interlocutores e perfeitamente respeitável na opinião deles. Ele procura mostrar que tomar vinho e mesmo ficar bêbado, se forem praticados em banquetes bem administrados, contribui para a educação da temperança ou moderação. Esse discurso sobre o vinho compõe o cerne dos dois primeiros livros das Leis. Somente após a conclusão do discurso sobre o vinho, o ateniense retorna à questão do início da vida política, uma questão que é o verdadeiro início de seu tema político. O discurso sobre o vinho parece ser a introdução à filosofia política.

Por que o diálogo platônico sobre política e leis começa com uma conversa tão longa sobre o vinho? Qual é a necessidade artística ou logográfica que exige isso? Os interlocutores na conversa sobre leis são velhos cidadãos de comunidades famosas por suas leis, por sua obediência e fidelidade às suas velhas leis. Tais homens compreendem bem o que viver sob leis significa. Eles são a perfeita encarnação do espírito das leis: justiça e legalidade. No entanto, suas próprias virtudes se tornam defeitos, se não se trata mais de preservar velhas leis, mas de buscar ou introduzir novas e melhores leis. Seus hábitos e suas competências fazem esses homens resistentes a sugestões para aperfeiçoamentos. $O$ ateniense os induz a participar de uma conversa sobre tomar vinho, sobre um prazer que é proibido a eles pelas suas velhas leis. A conversa sobre tomar vinho é uma espécie de exaltação do vinho pelo vinho, especialmente porque tomar vinho é um prazer proibido. Talvez a conversa lembre aos dois interlocutores de transgressões secretas e prazerosas que eles mesmos cometerem. O efeito da conversa sobre o vinho é, portanto, similar ao efeito de tomar-se o vinho propriamente dito: ele solta suas línguas, os torna jovens, os faz decididos, ousados, dispostos a inovar. Eles não devem tomar realmente o vinho, pois isso prejudicaria seu julgamento. Eles devem tomar vinho não de fato, mas no discurso. 
Isso significa, entretanto, que tomar vinho educa para a ousadia, para a coragem e não para a moderação, no entanto foi dito que tomar vinho leva à moderação. Vamos considerar, então, o outro participante na conversa, o filósofo ateniense. Duvidar da sacralidade do ancestral significa apelar do ancestral para o natural. Isso significa transcender todas as tradições humanas, toda a dimensão do que é meramente humano. Isso significa aprender a desprezar a ideia do humano como algo inferior, ou seja, deixar a caverna. Mas ao deixar a caverna, perde-se a visão da cidade, de toda a esfera política. Se o filósofo deve oferecer orientação política, ele deve retornar para a caverna; da luz do sol para o mundo das sombras; sua percepção deve ser enfraquecida; sua mente deve ser ofuscada. A exaltação do prazer do vinho por meio de uma conversa sobre vinho, que expande o horizonte dos velhos cidadãos acostumados à lei, limita o horizonte do filósofo. Mas essa ofuscação, essa aceitação da perspectiva política, essa adoção da linguagem do homem político, essa realização da harmonia entre a excelência do homem e a excelência do cidadão, ou entre sabedoria e obediência às leis, é, ao que parece, o mais nobre exercício da virtude da moderação: tomar vinho educa para a moderação. Pois moderação não é uma virtude do pensamento: Platão compara a filosofia à loucura, o oposto da sobriedade ou moderação; o pensamento não deve ser moderado, mas sem medo, para não dizer sem vergonha. Mas moderação é a virtude de controlar o discurso do filósofo.

Sugerimos que o estranho ateniense foi a Creta para civilizar uma sociedade atrasada e que ele agiu assim devido à filantropia. Mas a filantropia não começa em casa? Não teria ele outros assuntos mais urgentes para tratar em casa? Que tipo de homem é o estranho ateniense? O texto das Leis começa com a palavra "Deus": é o único diálogo platônico que começa dessa maneira. Há apenas um único diálogo que termina com a palavra "Deus": a Apologia a Sócrates. Na Apologia a Sócrates, um velho filósofo ateniense, Sócrates, defende-se contra a acusação de imoralidade, de não acreditar que os deuses venerados pela cidade de Atenas existiam. Parece que há um conflito entre a filosofia e a aceitação dos deuses da cidade. Nas Leis um velho filósofo ateniense recomenda uma lei sobre impiedade, que torna impossível o conflito entre a filosofia e a cidade, ou que as harmoniza. Os deuses cuja existência deve ser reconhecida por todo cidadão da cidade das Leis são seres 
cuja existência não pode ser demonstrada. Aquele velho filósofo ateniense da Apologia a Sócrates foi condenado à morte pela cidade de Atenas. Foi dada a ele a oportunidade de escapar da prisão: ele recusou a se dar essa oportunidade. Sua recusa não foi baseada no recurso a um imperativo categórico exigindo obediência passiva, sem "se" e "mas". Sua recusa foi baseada em uma deliberação, em uma prudente consideração do que seria a coisa certa dadas as circunstâncias. Uma das circunstâncias era a idade avançada de Sócrates: somos forçados a pensar sobre como Sócrates teria decidido se este tivesse 30 ou 40 anos em vez de 70 . Outra circunstância era a inexistência de um lugar adequado para o exílio: onde ele poderia se refugiar? Ele parece ter uma escolha entre as cidades legalistas das vizinhanças, onde sua vida seria insuportável, pois ele seria conhecido com um refugiado da justiça, e um país distante e sem leis, onde a falta de ordem tornaria a sua vida miserável. A comparação é obviamente incompleta: há cidades legalistas distantes, como, por exemplo, Creta, que é mencionada como um lugar legalista na própria deliberação em questão. Somos levados a inferir que, se Sócrates tivesse fugido, ele iria para Creta. As Leis nos dizem o que ele teria feito em Creta após a sua chegada: ele traria as bênçãos de Atenas, as leis atenienses, as instituições atenienses, banquetes e filosofia a Creta. (Quando Aristóteles fala das Leis de Platão, ele assume como fato de que o personagem das Leis é Sócrates). Escapar para Creta, viver em Creta, era a alternativa a morrer em Atenas. Mas Sócrates escolhe morrer em Atenas. Sócrates preferiu sacrificar sua vida para preservar a filosofia em Atenas em vez de preservar sua vida para introduzir a filosofia em Creta. Sua escolha foi uma escolha política da mais alta ordem. Não consistiu na simples consideração do seu caso sob uma regra simples, universal e inalterável.

Mas vamos retornar após essa longa história ao início das Leis de Platão. Se o criador das leis de Creta, ou de quaisquer leis, não é um deus, a causa das leis deve ser os seres humanos, o legislador humano. Há uma variedade de legisladores humanos: o legislador tem um caráter distinto em uma democracia, em uma oligarquia, em uma monarquia. O legislador é o corpo governante e o caráter do corpo governante depende do conjunto da ordem social e política, da politeia, do regime. A causa das leis é o regime. Portanto, o tema orientador do pensamento político é o regime e não as leis. $O$ 
regime se torna o tema orientador do pensamento político quando o caráter pouco original e questionável das leis foi realizado. Há um grande número de termos bíblicos que podem ser traduzidos adequadamente por "lei"; não há equivalente bíblico para "regime".

Regime é a ordem, a forma, que dá à sociedade seu caráter. Regime é, portanto, uma maneira específica de vida. Regime é a forma de vida, de viver junto, a maneira de viver da sociedade e na sociedade, uma vez que essa maneira depende decisivamente da predominância de seres humanos de certo tipo. Regime significa aquela totalidade que nós hoje temos o hábito de ver de uma forma fragmentada; regime significa simultaneamente a forma de vida de uma sociedade, seu estilo de vida, seu gosto moral, forma de sociedade, forma de governo, espírito das leis. Podemos tentar articular esse pensamento simples e unificado, que expressa em si o termo politeia, da seguinte maneira: vida é atividade que é direcionada a uma mesma meta; vida social é uma atividade que é direcionada a tal meta que pode ser buscada apenas pela sociedade; mas para buscar uma meta específica, que é uma meta abrangente, a sociedade deve estar organizada, ordenada, construída, constituída de uma maneira que está de acordo com essa meta; isso, entretanto, significa que os homens que detêm a autoridade devem estar sintonizados com essa meta.

Há uma variedade de regimes. Cada regime apresenta uma reivindicação, explícita ou implícita, que se estende além das fronteiras de qualquer sociedade. Essas reivindicações conflitam, portanto, umas com as outras. Há vários regimes conflitantes. Assim, os próprios regimes, e não nossa preocupação como meros observadores, forçam-nos a considerar qual dos regimes conflitantes é o melhor, e, em última instância, qual regime é o melhor. A filosofia política clássica é guiada pela questão do melhor regime.

A realização do melhor regime depende do agregar, da coincidência das coisas que têm uma tendência natural a se afastarem umas das outras, isto é, na coincidência da filosofia e do poder político; sua realização depende, portanto, da sorte. A natureza humana está escravizada de tantas maneiras que é quase um milagre quando um indivíduo alcança o bem supremo. O que esperar da sociedade? A maneira peculiar de ser o melhor regime - ou seja, sua falta de realização e ao mesmo tempo sua capacidade de ser superior a 
todos os regimes existentes - tem sua razão de ser na natureza dual do homem, no fato de que o homem é o ser intermediário que existe entre a vida dos brutos e aquela dos deuses.

O sentido prático da noção de melhor regime surge mais claramente quando se considera a ambiguidade do termo "bom cidadão". Aristóteles sugere duas definições totalmente diferentes de bom cidadão. Na sua mais popular Constituição de Atenas, sugere que o bom cidadão é um homem que serve bem a seu país, sem qualquer consideração à diferença entre regimes aquele que serve bem a seu país com uma indiferença fundamental em relação à mudança de regimes. O bom cidadão, em uma palavra, é o cidadão patriótico, o homem cuja lealdade pertence em primeiro lugar e em última instância à sua pátria. Em seu livro menos popular Política, Aristóteles diz que não pode haver o bom cidadão sem uma qualificação do termo, pois o que se entende por bom cidadão depende inteiramente do regime. Um bom cidadão na Alemanha de Hitler seria um mau cidadão em outros lugares. Mas enquanto ser um bom cidadão depende do regime, ser um homem bom não é tão relativo. O sentido de homem bom é sempre, e em qualquer lugar, o mesmo. O homem bom é idêntico ao bom cidadão apenas em um caso: no caso do melhor regime. Pois apenas no melhor regime o bom do regime e o bom dos homens são idênticos, sendo o bem, a virtude. Isso significa que a Política de Aristóteles questiona a proposição de que o patriotismo seja suficiente. Do ponto de vista do patriota, a pátria é mais importante que qualquer diferença de regimes. Do ponto de vista do patriota, aquele que prefere um regime à sua pátria é um partisan, se não um traidor. Aristóteles diz que o partisan vê mais profundamente do que o patriota, mas que apenas um tipo de partisan é superior ao patriota: é o partisan da virtude. Podemos expressar o pensamento de Aristóteles da seguinte forma: o patriotismo não é suficiente pelo mesmo motivo que a mãe mais devotada é mais feliz se seu filho for bom do que se ele for mau. Uma mãe ama seu filho, porque ele the pertence; ela ama o que é seu. Mas ela também ama o bem. Todo o amor humano se situa perante a lei para ser tanto o seu amor e o amor do bem, há necessariamente uma tensão entre o que é nosso e o que é o bem, uma tensão que pode levar a uma ruptura, ainda que resulte apenas em um coração partido. A relação entre o que é nosso e o bem encontra sua expressão 
política na relação entre pátria e regime. Na linguagem da metafísica clássica, a pátria ou a nação seria a matéria enquanto o regime seria a forma. Os clássicos sustentavam a visão de que a forma é superior em dignidade do que a matéria. Pode-se chamar essa visão de "idealismo". O sentido prático desse idealismo é que o bem é de uma dignidade superior a do próprio ser, ou que o melhor regime deve ter uma consideração mais elevada do que a pátria. Podese dizer que o equivalente judaico dessa relação é a relação entre a Torah e Israel.

A filosofia política clássica está hoje exposta a duas objeções muito comuns, cuja emergência não exige originalidade nem inteligência, nem mesmo erudição. As objeções são as seguintes: (1) a filosofia política clássica é antidemocrática e, portanto, má; (2) a filosofia política clássica é baseada na filosofia natural clássica ou na cosmologia clássica e o sucesso das ciências naturais modernas mostraram que essa base é falsa.

Iniciando pela atitude dos clássicos em relação à democracia, as premissas "os clássicos são bons" e "a democracia é boa" não validam a conclusão "portanto os clássicos são bons democratas". Seria tolo negar que os clássicos rejeitavam a democracia como um tipo inferior de regime, mas não estavam cegos para as suas vantagens. A condenação mais severa já feita à democracia está no oitavo livro da República de Platão. Mas, mesmo lá, Platão deixa claro - ao coordenar seu arranjo de regimes com o arranjo de Hesíodo das épocas do mundo - que a democracia é, em um aspecto muito importante, igual ao melhor regime que corresponde com a era de ouro de Hesíodo: uma vez que o princípio da democracia é a liberdade, todos os tipos humanos podem se desenvolver livremente nela, e, consequentemente, em especial, o melhor tipo humano. É verdade que Sócrates foi morto por uma democracia; mas ele foi morto quando tinha 70 anos; permitiram que ele vivesse 70 longos anos; na antidemocrática Esparta, ele teria sido abandonado e deixado para morrer ainda criança. No entanto, Platão não considerou esse aspecto como decisivo, pois ele estava preocupado não só com a possibilidade da filosofia, mas igualmente com uma ordem política estável que teria afinidades com ações políticas moderadas; e tal ordem, ele pensou, depende da predominância das velhas famílias. De forma mais geral, os clássicos rejeitavam a democracia, porque eles achavam que o objetivo da vida humana, 
e, portanto, da vida social, não era a liberdade, mas sim a virtude. A liberdade como finalidade é ambígua, porque é liberdade para o mal assim como para o bem. A virtude emerge, normalmente, apenas por meio da educação, ou seja, por meio da formação do caráter, por meio da ambientação, e isso exige o ócio tanto dos pais como dos filhos. Mas o ócio por sua vez exige algum grau de riqueza - mais especificamente um tipo de riqueza cuja aquisição ou administração é compatível com o ócio. Com relação à riqueza, como nota Aristóteles, há sempre uma minoria de pessoas bem de vida e uma maioria de pobres, e essa estranha coincidência durará para sempre, porque há uma espécie de escassez natural, "pois os pobres não poderão dispor da terra". É por essa razão que a democracia, ou o regime da maioria, é o governo dos não-educados. E ninguém em sã consciência desejaria viver sob tal governo. Esse argumento clássico não seria tão chocante, se os homens não precisassem de educação para adquirir uma ligação firme com a virtude. Não é por acaso que Jean-Jacques Rousseau, que ensinou que todo o conhecimento necessitado pelos homens para viver virtuosamente é fornecido pela consciência, que é a salvaguarda das almas simples mais do que dos demais homens - o homem está suficientemente equipado pela natureza para a boa vida; o homem é naturalmente bom - é o mesmo que foi levado a desenvolver um esquema de educação que poucas pessoas poderiam sustentar financeiramente. No geral, prevaleceu a visão de que a democracia deve se tornar o regime dos instruídos e essa finalidade seria alcançada pela universalização da educação. Mas a universalização da educação pressupõe que a economia da escassez dará lugar à economia da abundância, e a economia da abundância pressupõe a emancipação da tecnologia da moral e do controle político. A diferença essencial entre a nossa visão e a visão clássica consiste, portanto, não na diferença sobre um princípio moral, não em uma compreensão distinta da justiça. Nós também, e até os comunistas, com os quais coexistimos, pensamos que é justo dar coisas iguais a pessoas iguais e coisas desiguais a pessoas de mérito desigual. A diferença entre nós e os clássicos, em relação à democracia, consiste exclusivamente em uma estimativa diferente sobre as virtudes da tecnologia. Mas não podemos dizer que a visão clássica tem que ser refutada. Sua profecia implícita de que a 
emancipação da tecnologia, das artes, da moral e do controle político levaria a um desastre ou a desumanização do homem, ainda não foi refutada.

Nem podemos dizer que a democracia encontrou um problema para a educação. Em primeiro lugar, o que chamamos hoje de educação, muitas vezes, não significa educação propriamente dita, isto é, a formação do caráter, mas sim instrução e treinamento. Em segundo lugar, na medida em que a formação do caráter é de fato a intenção, há uma tendência muito perigosa de identificar o homem bom com o homem afável, com o indivíduo cooperativo, com o cara mediano, ou seja, há uma ênfase excessiva em uma parte da virtude social e uma negligência correspondente às virtudes que emergem e maturam na privacidade, para não dizer na solidão. Ao educar pessoas para cooperarem umas com as outras em um espírito amigável, não se educa o não-conformista, pessoas preparadas para se colocarem e lutarem sozinhas, os "individualistas inflexíveis". A democracia ainda não encontrou uma defesa contra o conformismo crescente e a intensificação da invasão de privacidade que ela promove. Os seres que olham para nós das estrelas podem achar que a diferença entre democracia e comunismo não é tão grande quanto parece ser quando se considera exclusivamente a questão, muito importante sem dúvida, das liberdades políticas e civis, embora apenas pessoas de excepcional leviandade ou irresponsabilidade possam dizer que a diferença entre comunismo e democracia é ínfima no último caso. Agora, na medida em que a democracia é consciente desses perigos, na mesma medida ela se vê induzida a pensar em elevar o seu nível e o suas possibilidades por meio de um retorno às noções clássicas da educação: um tipo de educação que não pode nunca ser pensada como uma educação de massa, mas apenas como a educação elevada e superior daqueles que são, por natureza, predispostos para ela. Seria compreensível chamá-la de educação nobre.

No entanto, considerando-se que não existem objeções morais ou políticas à filosofia clássica, será que a filosofia política não estaria ligada a uma cosmologia antiquada? Não é o caso de considerar que a questão da natureza do homem aponta para a questão da natureza do todo, e com isso para outra cosmologia específica? Seja qual for a importância que a ciência natural moderna possa ter, ela não pode afetar a nossa compreensão do que é humano no homem. Compreender o homem da perspectiva do todo significa 
para as ciências naturais compreender o homem a partir da perspectiva do sub-humano. Mas nessa perspectiva o homem como tal é totalmente ininteligível. A filosofia política clássica via o homem de uma perspectiva diferente. Isso começou com Sócrates e ele estava tão longe de se comprometer com uma única cosmologia que seu conhecimento era 0 conhecimento da ignorância. O conhecimento da ignorância não é ignorância; é o conhecimento do caráter elusivo da verdade, do todo. Sócrates, então, viu o homem sob a luz do caráter misterioso da verdade, do todo. Ele sustentava que estamos mais familiarizados com a situação do homem como tal, do que com as causas últimas dessa situação. Podemos dizer que ele viu o homem sob a luz de ideias imutáveis, isto é, dos problemas fundamentais e permanentes. Pois articular a situação do homem significa articular a abertura do homem ao todo. Essa compreensão de que a situação do homem inclui, portanto, a busca por uma cosmologia em lugar de uma solução para o problema da cosmologia, foi o fundamento da filosofia política clássica.

Articular o problema da cosmologia significa responder à questão sobre o que é a filosofia e o que é o filósofo. Platão não delegou a discussão dessa temática a Sócrates. Ele confiou a questão a um estranho de Elea. Mas mesmo esse estranho de Elea não discute explicitamente o que é o filósofo. Ele discute explicitamente dois tipos de homens que são comumente confundidos com o filósofo, o sofista e o homem de Estado. Ao compreender o que são esses dois tipos de homens, compreende-se o que é filosofia. A filosofia busca o conhecimento do todo. O todo é a totalidade das partes. $O$ todo nos confunde, mas nós conhecemos as partes: possuímos o conhecimento parcial das partes. O conhecimento que temos é caracterizado por um dualismo fundamental que nunca foi superado. Em um polo, encontramos o conhecimento da homogeneidade, acima de tudo na aritmética, mas também em outros ramos da matemática, e por derivação em todas as artes produtivas ou nos artefatos. No polo oposto, encontramos 0 conhecimento da heterogeneidade e, em especial, de fins heterogêneos; a forma mais elevada desse tipo de conhecimento é a arte do homem de Estado e do educador. Essa segunda forma de conhecimento é superior à primeira pela seguinte razão. Dado que o conhecimento dos fins da vida humana é o conhecimento do que faz a vida humana completa, ou inteira; é, portanto, o 
conhecimento do todo. O conhecimento dos fins do homem requer 0 conhecimento da alma humana; e a alma humana é apenas parte do todo que está aberta ao todo e, portanto, mais próxima do todo do que qualquer outra coisa. Mas esse conhecimento - a arte política no seu sentido mais elevado - não é o conhecimento do todo. Parece que o conhecimento do todo deve combinar de algum modo o conhecimento político em seu sentido mais elevado como conhecimento da homogeneidade. E essa combinação não está a nossa disposição. Portanto, os homens são constantemente tentados a forçar a questão impondo unidade ao fenômeno, tornando absoluto ou o conhecimento da homogeneidade ou dos fins. Os homens são constantemente atraídos e confundidos por dois apelos: o apelo da competência que é engendrado pela matemática e tudo o que é próximo à matemática, e o apelo da admiração modesta, que é engendrada pela meditação da alma humana e suas experiências. A filosofia é caracterizada pela recusa gentil, porém firme, de sucumbir a ambos os apelos. É a mais alta forma de cruzamento da coragem com a moderação. Apesar de sua elevada posição ou nobreza, pode parecer sisifiana ou feia quando se comparam suas realizações com os seus objetivos. No entanto, a filosofia é necessariamente acompanhada, sustentada e elevada por eros. É adornada pela a graça da natureza. 